Copyright by the American Society of Agricultural and Biological Engineers. Shukla, S.; Mostaghimi, S.; Burger, J. A., "Laboratory measurements and modeling $\mathrm{N}$ mineralization potential in Virginia Coastal Plain agricultural, fallow, and forest soils," Transactions of the ASAE. VOL. 43(2): 315-325 . (doi: 10.13031/2013.2707) @2000

\title{
Laboratory Measurements and Modeling N Mineralization Potential in Virginia CoAstal Plain Agricultural, FALLOW, AND FOREST SOILS
}

\author{
S. Shukla, S. Mostaghimi, J. A. Burger
}

\begin{abstract}
A long-term aerobic incubation and leaching technique was used to measure $N$ mineralization of surface and subsurface soils (sandy loam) from agricultural, forest, and fallow sites in a Virginia Coastal Plain watershed. $N$ mineralization potential was measured to refine models used to describe this process in a watershed-scale nutrient export assessment. Potentially mineralizable $N\left(N_{0}\right)$ and reaction rate constants $(k)$ were estimated using a first-order model and a nonlinear regression procedure. Large variations in cumulative $N$ mineralized, $N_{O}$, and $k$, were found for the surface soils from agricultural areas. Forest soils had much higher potentially mineralizable $N$ than agricultural soils. For subsurface soils, the differences among land uses were less variable than those observed for the surface soils. The firstorder model (single-pool approach) was adequate for predicting $N$ mineralization in surface soils from agricultural and fallow areas, but less suitable for forest surface soils. Consideration of a double exponential (two-pool approach) model did not improve the performance of $N$ mineralization prediction for forested or agricultural soils. Large variations occurred in the field-predicted values of mineralized $N$ due to temperature and moisture ranges commonly occurring throughout the season. Variability in the $N$ mineralization potential of soils in the watershed suggests that individual $k$ and $N_{O}$ should be derived for soils with similar properties to obtain better predictions of $N$ mineralization and thus $N$ movement to groundwater.
\end{abstract}

Keywords. Organic N, Inorganic N, Model, Land use.

$\mathrm{N}$ itrogen (N) mineralization, an important component of the soil $\mathrm{N}$ cycle, is a complex process in which a variety of microorganisms (bacteria, fungi, and actinomycetes) use a wide array of substrates (crop residues, soil humus, dead microbial tissue, and manure) under variable soil environments (temperature, water content, and aeration) to produce $\mathrm{NH}_{4}-\mathrm{N}$. $\mathrm{NH}_{4}-\mathrm{N}$ is further transformed to $\mathrm{NO}_{3}-\mathrm{N}$ via nitrification, another biological process involving autotrophic bacteria. Mineralization and nitrification processes occur concurrently in soils. The $\mathrm{NO}_{3}-\mathrm{N}$ produced can be used by plants, lost to the atmosphere through denitrification, immobilized by soil microorganisms, accumulate in the soil, or be leached from the soil-crop system (Schepers and Meisinger, 1994). N mineralization is defined as the conversion of organic $\mathrm{N}$ to inorganic $\mathrm{N}$ through microbial activity, while $\mathrm{N}$ immobilization is defined as the conversion of inorganic $\mathrm{N}$ to organic $\mathrm{N}$ in microbial tissue (SSSA, 1987). Quantification of $\mathrm{N}$ mineralization is crucial in the design of efficient $\mathrm{N}$ management strategies in order to achieve sustained crop productivity with minimal negative environmental impact.

Article was submitted for publication in February 1999; reviewed and approved for publication by the Soil \& Water Division of ASAE in January 2000. Presented as ASAE Paper No. 98-2013.

The authors are Sanjay Shukla, ASAE Student Member, Senior Research Assistant, and Saied Mostaghimi, ASAE Member Engineer, Professor, Biological Systems Engineering Department, Seitz Hall, and James A. Burger, Professor, Forestry Department, Cheatham Hall, Virginia Tech, Blacksburg, Virginia. Corresponding author: Saied Mostaghimi, Virginia Tech, Biological Systems Engineering Dept. Blacksburg, VA-24061-0303, phone: 540.231.7605, fax: 540.231-3199, email: <smostagh@vt.edu>.
Estimation of potentially mineralizable $\mathrm{N}$ through longterm laboratory studies was first proposed by Stanford and Smith (1972), who demonstrated that the $\mathrm{N}$ mineralization reaction follows first-order kinetics. Consequently, several studies have utilized long-term incubation techniques to estimate the potentially mineralizable $\mathrm{N}\left(\mathrm{N}_{0}\right)$ and firstorder rate constant $(\mathrm{k})$ for predicting $\mathrm{N}$ mineralization for a variety of purposes, such as plant available $\mathrm{N}$, fertilizer recommendation, and estimating $\mathrm{N}$ leaching to groundwater.

The main goal of this study was to quantify $\mathrm{N}$ mineralization in soils with different land uses for watershed-scale $\mathrm{N}$ balance modeling. The specific objectives of this study were to: (1) quantify the potentially mineralizable $\mathrm{N}$ in agricultural, fallow, and forested soils (surface and subsurface) in a Virginia Coastal Plain watershed; (2) determine the effect of land use on $\mathrm{N}$ mineralization; and (3) develop single and double exponential models to predict $\mathrm{N}$ mineralization. This study utilizes the long-term laboratory incubation technique for estimating the potentially mineralizable $\mathrm{N}$ for surface and subsurface soils from cropland, forested, and fallow areas.

\section{Materials AND Methods}

SOILS AND SAMPLING

Soils from 14 sites in the Nomini Creek watershed (area $=1500$ ha) located in Westmoreland County in the Virginia Coastal Plain region were included in this study. The soils in the watershed are Ultisols. Soil texture for most of the soils in the watershed (including the 14 sites) is sandy loam. Locations of the 14 sites are shown in figure 1. Information on type, land use, and management history of these soils are given in table 1 . These sites were selected to 


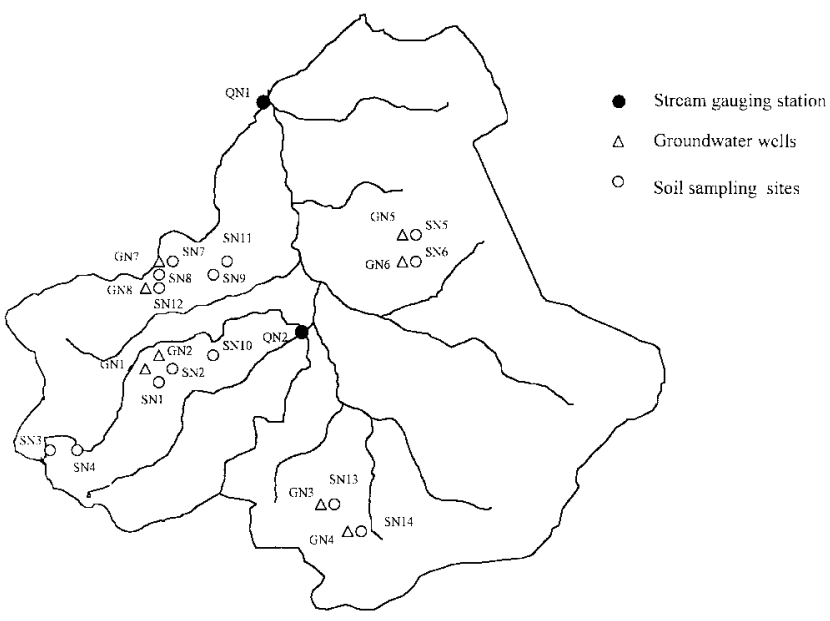

Figure 1-Soil sampling sites in the Nomini Creek watershed, Westmoreland County, Virginia.

Table 1. Background information about the soil sampling sites

\begin{tabular}{lll}
\hline Sites & Land Use & Description \\
\hline AG*-1 & Crop Land & Corn-Small Grain-Soybean \\
AG-2 & Crop Land & Corn-Small Grain-Soybean \\
AG-3 & Crop Land & Corn-Small Grain-Soybean \\
AG-4 & Crop Land & Corn-Small Grain-Soybean \\
AG-5 & Crop Land & Corn-Small Grain-Soybean \\
AG-6 & Crop Land & Corn-Small Grain-Soybean \\
AG-7 & Crop Land & Corn-Small Grain-Soybean \\
AG-8 & Crop Land & Corn-Small Grain-Soybean \\
FOR $†-9$ & Forest & Loblolly Pine (25 year stand) \\
FOR-10 & Forest & Loblolly Pine (25 year stand) \\
FOR-11 & Forest & Loblolly Pine (25 year stand) \\
FAL $\ddagger-12$ & Fallow & Taken out of agricultural production in 1988 \\
& & under CRP and planted with Bermuda grass \\
AG-13 & Crop Land & Corn-Small Grain-Soybean \\
AG-14 & Crop Land & Corn-Small Grain-Soybean \\
\hline
\end{tabular}

* Agricultural sites.

$\dagger$ Forest sites

F Fallow site.

supplement the soil and groundwater $\mathrm{N}$ transport data monitored for two years at all these locations (Mostaghimi et al., 1989) and a three-year $\mathrm{N}$ leaching study at one of the sites. This study was performed to fill the data gap for $\mathrm{N}$ mineralization in order to perform a watershed-scale $\mathrm{N}$ mass balance modeling effort (Shukla and Mostaghimi, 1998).

Ten of the 14 sites are located in agricultural fields with a typical corn-small grain-soybean rotation. Eight of the 10 agricultural sites, are located close to the eight wells (fig. 1) used for monitoring the monthly groundwater $\mathrm{N}$ concentrations for 11 years (1986-1997). These wells were drilled in pairs. The four well pairs were located in four different agricultural fields. The odd numbered wells are located in up-gradient areas of the field; whereas, the even numbered wells are located in the down-gradient area. The notation " $\&$ " (e.g., 1\&2) is used herein to refer to the two sites. Soil sampling sites $1 \& 2,5 \& 6,7 \& 8$, and $13 \& 14$ are located near the well pairs $1 \& 2,5 \& 6,7 \& 8$, and $3 \& 4$, respectively (fig. 1$)$. The three forested sites $(9,10$, and 11$)$ are populated mostly with loblolly pine. The average age for the stand is 25 years. The "fallow" site (12) is located downgradient from the agricultural site 7 . The fallow site was part of the agricultural field (sites 7 and 8) until 1988.
Due to its steep slope and proximity to the stream draining the agricultural site, the area was taken out of agricultural production and planted with Bermuda grass under the conservation reserve program (CRP).

Soil samples were taken from the surface $(0$ to $20 \mathrm{~cm}$, plow layer) and subsurface (20 to $40 \mathrm{~cm}$ ) layers at each site in December 1996. Before taking the samples at each site, tube augers were inserted in the soil at 10 neighboring locations to determine the average depths of the plow layer and the subsurface layer (immediately after the plow layer). These two layers were assumed to have most of the organic $\mathrm{N}$ and therefore potentially mineralizable $\mathrm{N}$. After determining the depth of the two layers, soil samples were taken with a bucket auger (diameter $=8.5 \mathrm{~cm}$ ) from each layer. For each site, soil samples from the neighboring areas were mixed together to get a composite sample for each of the surface and subsurface layers. A total of 28 composite soil samples were taken (14 sites $\times 2$ layers). Samples were bagged in the field and brought to the laboratory at Virginia Tech, where they were kept in a cooler at $4^{\circ} \mathrm{C}$ prior to $\mathrm{N}$ mineralization study. Samples were passed through a 2-mm sieve. Each of the 28 samples were divided into two sub-samples to make two laboratory replications for each treatment (site, layer). These replicate samples were also used for measuring soil Total Kjeldahl Nitrogen (TKN), $\mathrm{NH}_{4}, \mathrm{NO}_{3}$, organic $\mathrm{C}$, and soil $\mathrm{pH}$.

\section{N Mineralization Procedure}

The apparatus employed in this study was designed by the Forestry Department (Burger, 1995) at Virginia Tech. The method used for $\mathrm{N}$ mineralization procedure is similar to that of Stanford and Smith (1972) and modified by Burger and Pritchett (1984), which utilizes long-term aerobic incubation at $35^{\circ} \mathrm{C}$ (optimum temperature for mineralization) with periodic leaching to evaluate the mineralized $\mathrm{N}$.

PVC pipes ( $4 \mathrm{~cm}$ diameter and $0.4 \mathrm{~cm}$ thickness) were cut to make leaching columns of $18.5 \mathrm{~cm}$ length (fig. 2). For each treatment, two leaching columns ( 2 replications) were prepared to measure $\mathrm{N}$ mineralization. This resulted in a total of 56 columns $(14$ sites $\times 2$ layers $\times 2$ lab replications). The mineralization leaching columns were prepared as shown in figure 2 . The preparation of each leaching column involved mixing $60 \mathrm{~g}$ soil with $150 \mathrm{~g}$ washed sand to obtain a homogeneous mixture. Mixing with sand facilitated proper leaching and minimized particle size segregation. The sample was placed in the column and capped with a one-hole stopper, $1-\mathrm{cm}$ polyester fiber, 934-AH Whatman Glass Microfibre filter, and $10 \mathrm{~g}$ sand on both the ends. The glass filter protected the soil from dispersion when the solution passed through the columns. To minimize sediment buildup on filters and maximize leaching rate, columns were inverted after each leaching before being transferred to the incubation chamber. Duplicate 15-g soil samples were also used for measuring the soil moisture content of soil for converting the mineralized $\mathrm{N}$ to a dry weight basis (mg of min-N per $1 \mathrm{~g}$ of dry soil).

After preparation, the leaching columns were transferred to an incubation chamber maintained at $35^{\circ} \mathrm{C}$. After a week, the mineral $\mathrm{N}$ initially present was removed by leaching the column with $250 \mathrm{~mL}$ of $0.01 \mathrm{M} \mathrm{CaCl}_{2}$ solution. The solution was first allowed to leach by gravity, 


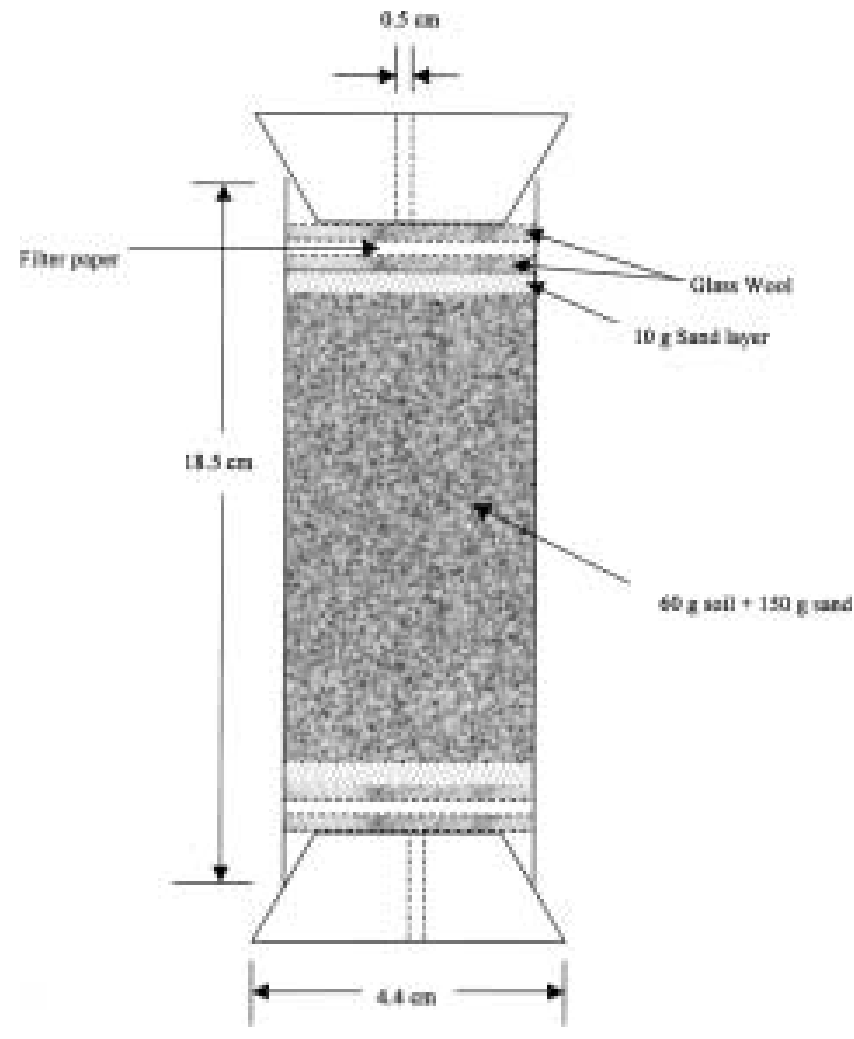

Figure 2-Schematic for $\mathbf{N}$ mineralization leaching column.

then a suction of $50 \mathrm{kPa}$ was applied through a vacuum pump for five minutes. The solution obtained from the first leaching was discarded; however, for subsequent leaching, this solution was weighed and analyzed for $\mathrm{NH}_{4}-\mathrm{N}$ and $\mathrm{NO}_{3}-\mathrm{N}$. After leaching with the $\mathrm{CaCl}_{2}$ solution, the column was leached with a minus- $\mathrm{N}$ nutrient solution $(0.002 \mathrm{M}$ $\mathrm{CaSO}_{4} \cdot 2 \mathrm{H}_{2} \mathrm{O}+0.002 \mathrm{M} \mathrm{MgSO}{ }_{4}+0.002 \mathrm{M} \mathrm{Ca}$ $\left.\left(\mathrm{H}_{2} \mathrm{PO} 4\right)_{2} \cdot \mathrm{H}_{2} \mathrm{O}+0.0025 \mathrm{~K}_{2} \mathrm{SO}_{4}\right)$ to replenish the essential nutrients in the soil after each leaching. The minus-N solution was first allowed to pass through the column under gravity after which a suction of $50 \mathrm{kPa}$ was applied for five minutes to remove the excess solution. Leachate from the minus-N solution was discarded. The leaching procedure was repeated after $1,1,1,2,2,2,2,2,5,5$, and five weeks (cumulative 1, 2, 3, 5, 7, 9, 11, 13, 18, 23, and 28 weeks) to determine mineral $\mathrm{N}$ leached during these periods. Loss of water during the incubation was assumed to be small. Mineral $\mathrm{N}$ in the leachate was analyzed using a Technicon AutoAnalyzer II.

Cumulative mineralized $\mathrm{N}$ was determined for each incubation period mentioned above. For post 18 -week leaching, the trends in the rates of $\mathrm{N}$ mineralization were examined to determine if the leaching should continue. Since by the twenty-eighth week the mineral N production rates became almost constant, the leaching experiment was stopped. The soil and sand mixtures from the columns were taken out and their $\mathrm{pH}$ measured to determine the change in soil chemistry as a result of mineralization and nitrification.

\section{Mineralization Modeling}

The first-order model proposed by Stanford and Smith (1972) was fitted to the laboratory $\mathrm{N}$ mineralization data obtained in this study to estimate the $\mathrm{N}$ mineralization potential $\left(\mathrm{N}_{0}\right)$ and the reaction rate constant $(\mathrm{k})$. These parameters were then used to model the cumulative $\mathrm{N}$ mineralized for a given period. The first order model is:

$$
\mathrm{N}_{\min }=\mathrm{N}_{0}\left(1-\mathrm{e}^{-\mathrm{kt}}\right)
$$

where $\mathrm{N}_{\min }$ is the amount of $\mathrm{N}$ mineralized $\left(\mathrm{mg} \mathrm{kg}^{-1}\right)$ at time $\mathrm{t}$ (week), $\mathrm{N}_{0}$ is the amount of potentially mineralizable $\mathrm{N}$, and $\mathrm{k}$ is the first-order reaction rate constant (week ${ }^{-1}$ ) or $\mathrm{N}$ mineralization rate constant. The first-order model (eq. 1) was fit to the mineral-N data by a nonlinear regression procedure (iterative approach) using Marquadt's and Newton's method in SAS (SAS Inst., 1997). Since a nonlinear regression procedure was used to fit the firstorder model to the $\mathrm{N}$ mineralization data, it is important to evaluate the errors in estimating $\mathrm{N}_{0}$ and $\mathrm{k}$. To evaluate goodness of fit of the first-order model, the mean squared error $(\mathrm{MSE}=$ residual sum of squares/degrees of freedom) obtained from SAS was used. Among the two fitting methods, Marquadt provided the better fit since for almost all the treatments it resulted in a lower mean square residual. Estimates of $\mathrm{N}_{0}$ and $\mathrm{k}$ from the Marquadt method are discussed in this study.

\section{RESULTS AND DisCUSSION \\ The InCUbATION STUDY}

N Mineralization Rates. Weekly N production rates for all the treatments decreased over time. An example of this pattern is shown in figure 3 for surface soils from two agricultural (sites 7 and 8; data in figure 3 are average of $7 \& 8$ ), one forested (site 9), and the fallow site (site 12). These four sites are located within $50 \mathrm{~m}$ of each other (fig. 1). Site 7 and 8 are located at the up-gradient and down-gradient slope in an agricultural field. This field is between the forested site (site 9) and fallow site (site 12). As shown in figure 3, the $\mathrm{N}$ mineralization rate was highest during the first week for all three soils. Surface soil from the forested site (site 9) had the highest $\mathrm{N}$ mineralization rate followed by the fallow soil and the agricultural soils. For all the treatments, rate of decrease in min-N production was highest during the first two weeks of the experiment. For forested soils this decline was most rapid with a $45 \%$

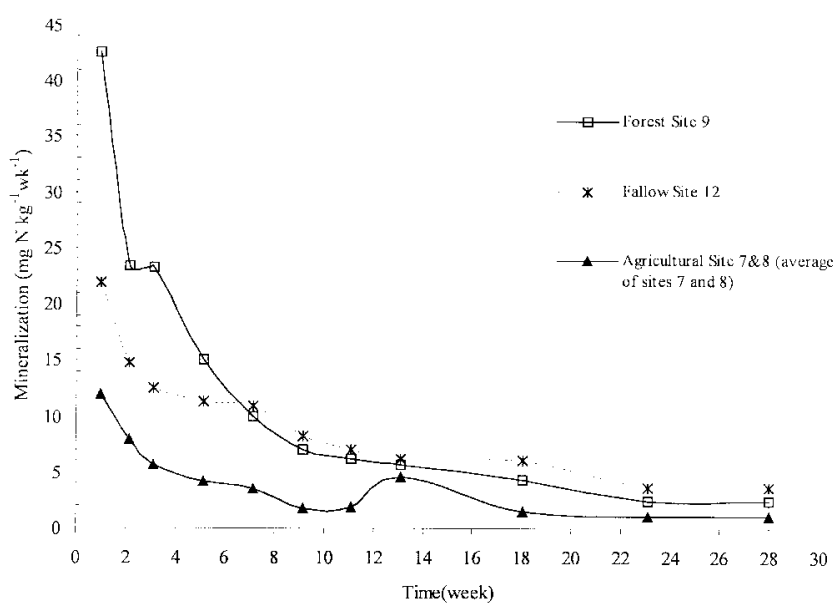

Figure 3-N mineralization rates during 28 weeks of incubation for agricultural, forest, and fallow surface soils. 
reduction in min-N production from week 1 to week 2 . The reductions in min- $\mathrm{N}$ production during the same period were $34 \%$ and $33 \%$ for the fallow soil and the agricultural soil (average of sites 7 and 8), respectively.

During week 13, the two agricultural soils showed a slight increase in the min-N production rate, which may be due to the quality of the substrate in agricultural soil. It has been argued that the organic $\mathrm{N}$ content of some soils can be divided into two pools: the readily mineralizable (labile) pool and the recalcitrant (slow mineralizable) pool (Deans et al., 1986; Cabrera et al., 1994). The labile organic $\mathrm{N}$ pool decomposes much faster than the recalcitrant pool and contributes to an initial flush of $\mathrm{N}$ mineralization as shown in figure 3 (Deans et al., 1986; Cabrera et al., 1994). The increased $\mathrm{N}$ mineralization rate during weeks 11 and 13 for agricultural soil (average of sites $7 \& 8$ ) may be attributed to the increased $\mathrm{N}$ mineralization from the recalcitrant pool. This increased pattern was observed for other agricultural soils included in this study (sites $1 \& 2,3 \& 4,5 \& 6$, and 13\&14; data not

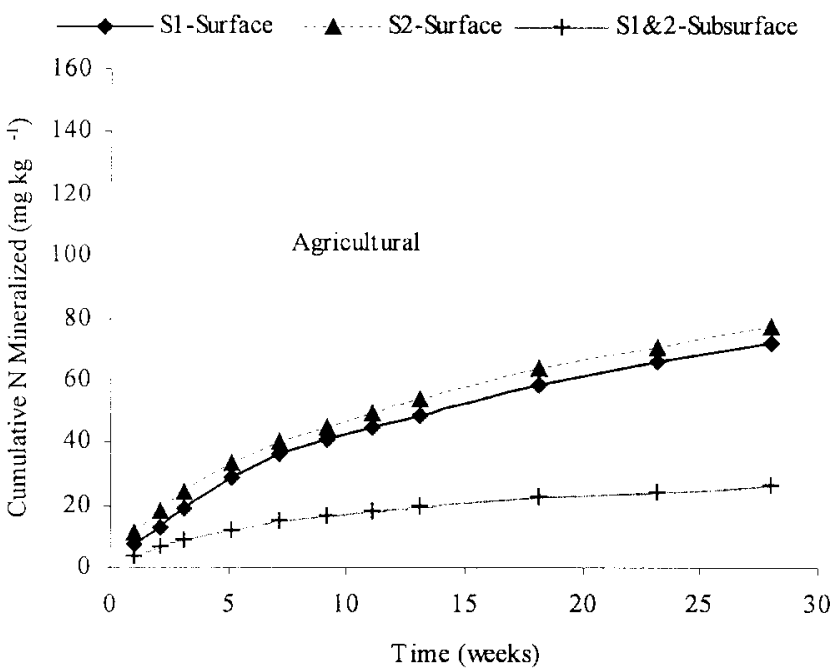

(a)

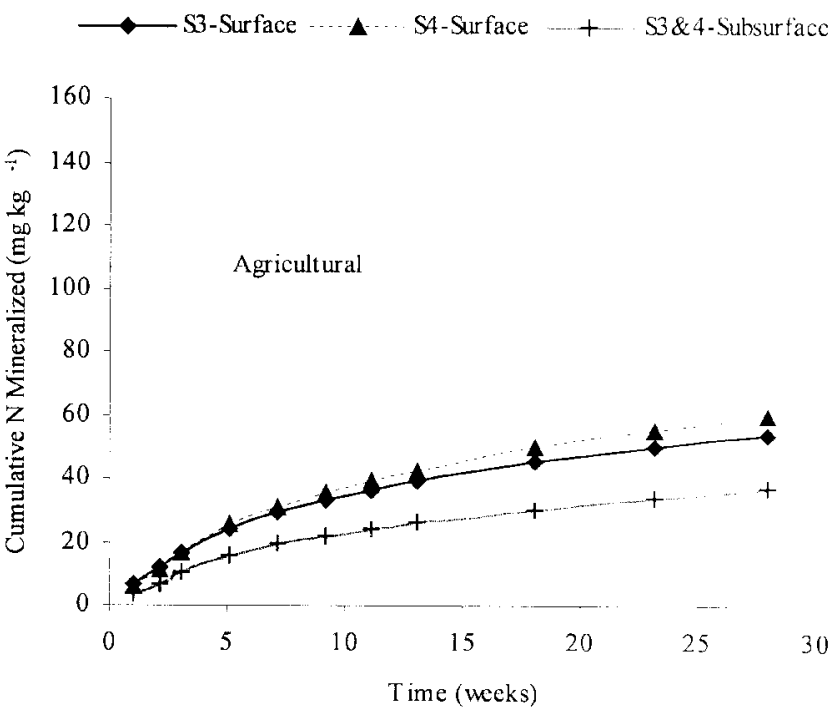

(b) shown); however, the extent and time of this increase varied depending on the site. The change in min- $\mathrm{N}$ rate from weeks 23 to 28 is almost negligible for all the four treatments, indicating that after 23 weeks the change in mineralization rates stabilized and began approaching zero. This provided the justification for terminating the incubation at the twenty-eighth week for this study.

Cumulative Mineralized N. Trends in the cumulative $\mathrm{N}$ mineralized (cum-min $\mathrm{N}$ ) during the 28-week period for all the treatments are shown in figure 4. Values for the cum-min $\mathrm{N}$ for all treatments are presented in table 2 .

For surface agricultural soils at sites $1 \& 2,3 \& 4$, and $7 \& 8$, the cumulative $\mathrm{N}$ mineralized in different periods for up-gradient and down-gradient sites did not differ considerably (fig. 4 a,b,d). However, for surface soils from agricultural sites $5 \& 6$ (fig. $4 \mathrm{c}$ ) and $13 \& 14$ (fig. $4 \mathrm{~g}$ ), the differences among the up-gradient and down-gradient were larger. Examination of the cumulative mineralized $\mathrm{N}$ trends for all the agricultural sites reveals that, with exception of

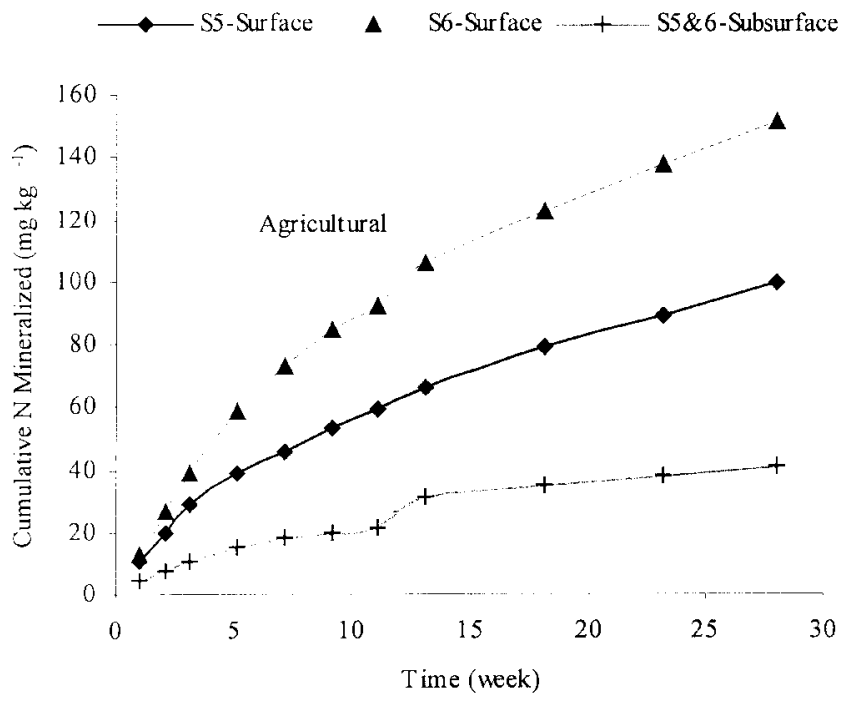

(c)

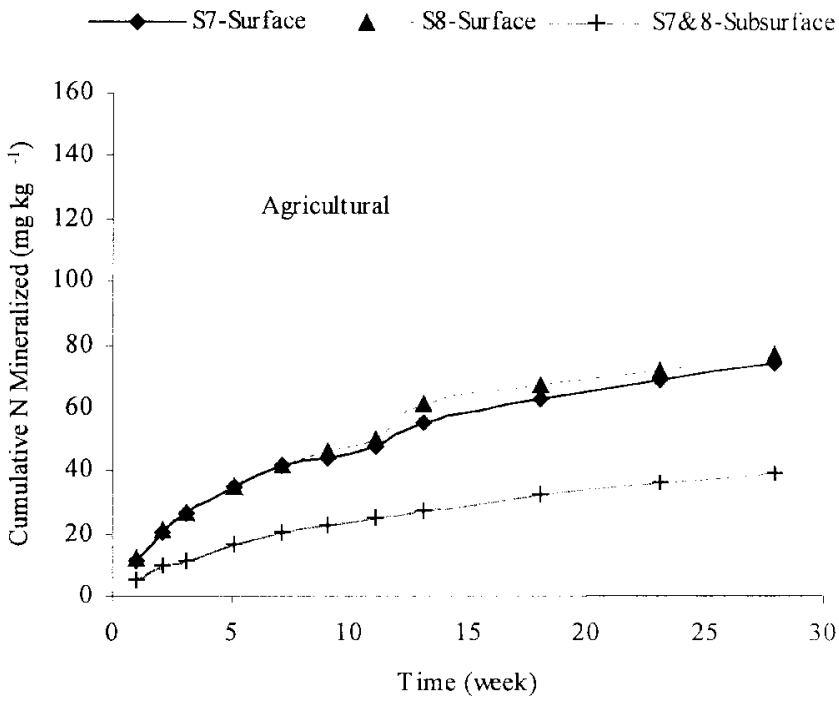

(d)

Figure 4-Cumulative mineralized $\mathrm{N}\left(\mathrm{mg} \mathrm{kg}^{-1}\right)$ for surface and subsurface soils. 


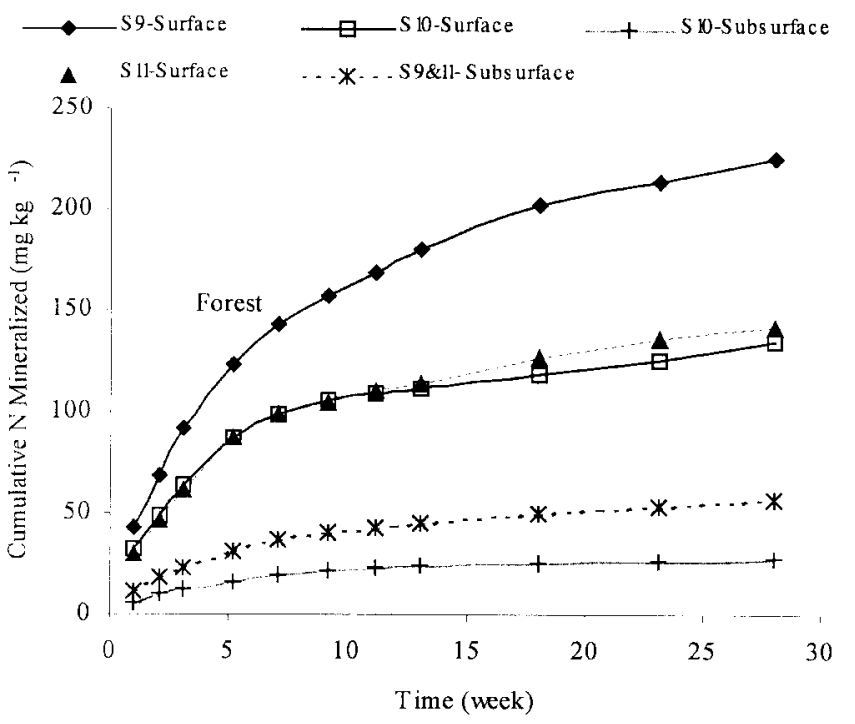

(e)

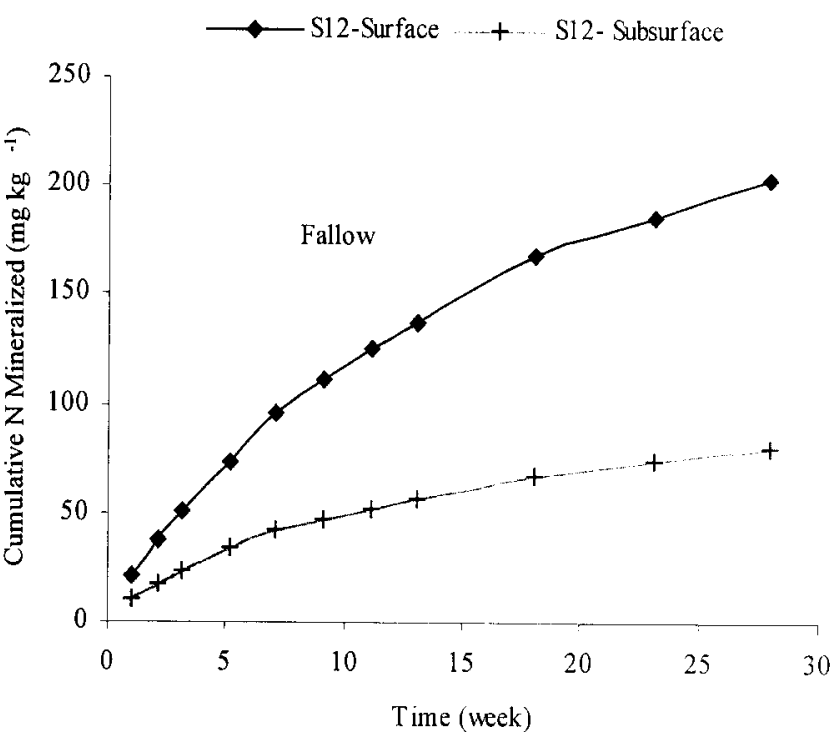

(f)

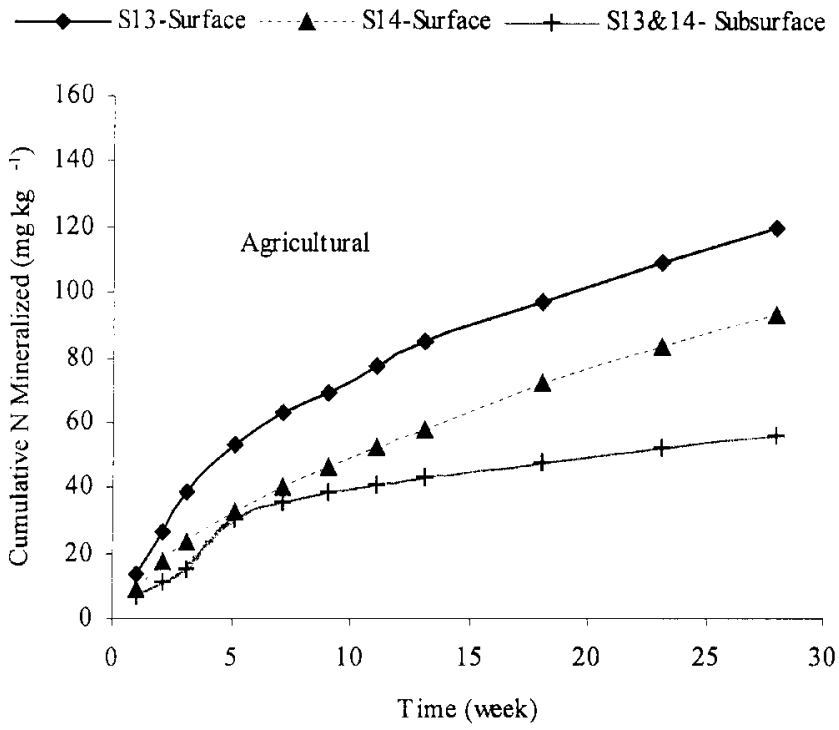

(g)

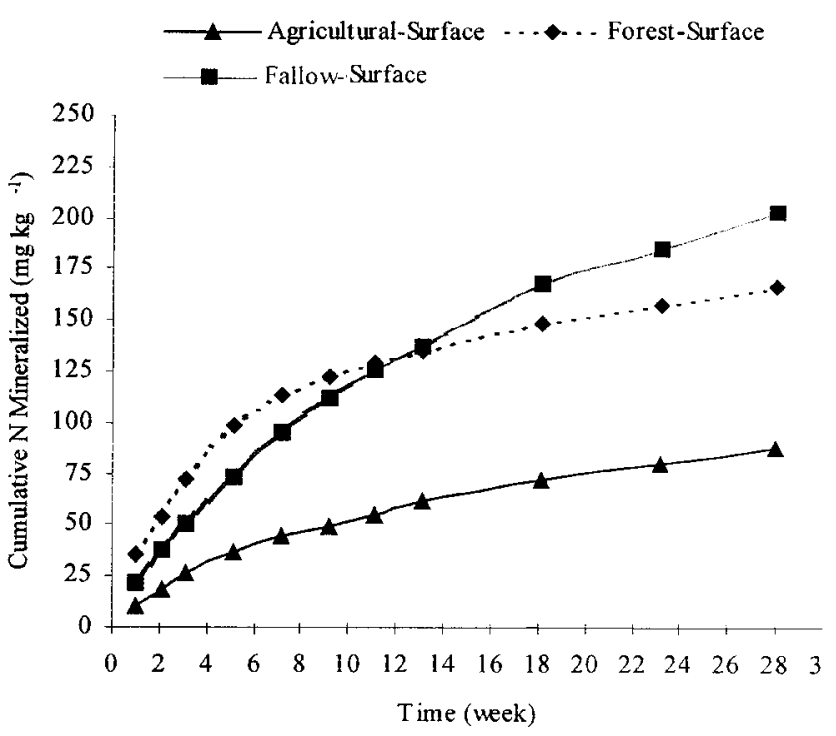

(h)

Figure 4 (cont.)-Cumulative mineralized $\mathbf{N}\left(\mathrm{mg} \mathrm{kg}^{-1}\right)$ for surface and subsurface soils.

sites $13 \& 14$ the cumulative $\mathrm{N}$ mineralization for downgradient sites was higher than that of the up-gradient site (site $2>$ site 1 ; site $4>$ site 3 ; site $6>$ site 5 ; site $8>$ site 7 ) (fig. 1a-d). A possible explanation can be the movement of soluble organic matter (organic $\mathrm{N}$ ) to the down-gradient sites, combined with the soil erosion from the upgradient site over time. It can be argued that soluble organic $\mathrm{N}$ is more readily mineralized than the insoluble organic $\mathrm{N}$. However, we could not find a study that investigated such comparisons to support the above inference.

For the three forested treatments, surface soils from site 9 seem to have much higher cum-min $\mathrm{N}$ in 28 weeks than the other two forested soils (fig. 4e). No obvious reason could be offered for this observation, except that site 9 had tree roots all around it which made it difficult to take the soil samples. Comparison of cum-min $\mathrm{N}$ trends for the surface soils of the forested areas with agricultural areas shows that forested areas have much higher cum-min
$\mathrm{N}$ than the agricultural areas. However, differences in cum$\min \mathrm{N}$ for the subsurface soils are much lower than those measured for the surface soils (table 2). The smaller differences for the subsurface treatments can be attributed to the fact that the soil type for all the treatments included in this study is the same. Therefore, the differences in the topsoil are directly related to the differences in land uses (forested versus agricultural), and thus the type of organic matter accumulation in the surface soils. Cabrera (1986) reported that the slowly-mineralizable $\mathrm{N}$ pool decreases with depth; whereas, the fast pool remains almost constant, or tends to decrease with depth. Therefore, it can be argued that considerably higher cum-min $\mathrm{N}$ for forest surface soils is possibly due to the fact that the slow pool of organic $\mathrm{N}$ for the surface forested soils (leaves and twigs) is much higher than in the agricultural areas. On the other hand, lower differences for subsurface forested and agricultural 
Table 2. Soil physical and chemical properties, and cumulative mineralized $\mathbf{N}$ in 28 weeks for surface and subsurface soils at the 14 locations

\begin{tabular}{|c|c|c|c|c|c|c|c|c|}
\hline Soil & $\begin{array}{l}\text { Depth } \\
(\mathrm{cm})\end{array}$ & $\begin{array}{l}\text { Soil pH } \\
\text { Before* }\end{array}$ & After $\dagger$ & $\underset{\left(\mathrm{Mg} / \mathrm{m}^{3}\right)}{\mathrm{BD}}$ & $\begin{array}{l}\text { Org. } \mathrm{C} \ddagger \\
(\%)\end{array}$ & $\begin{array}{l}\text { Org. N\& } \\
\left(\mathrm{mg} \mathrm{kg}^{-1}\right)\end{array}$ & $\begin{array}{c}\text { Cum. } \\
\text { Min. N\| } \\
\left(\mathrm{mg} \mathrm{kg}^{-1}\right)\end{array}$ & $\begin{array}{l}\% \text { Org N } \\
\text { Mineral. }\end{array}$ \\
\hline AG\#-1-T** & $0-20$ & 6.3 & 6.6 & 1.68 & 0.51 & 496.6 & 72.2 & 15 \\
\hline AG-2-T & $0-25$ & 6.5 & 6.6 & 1.58 & 0.54 & 485.5 & 77.1 & 16 \\
\hline AG-1\&2-SS + & $25-45$ & 5.9 & 6.7 & 1.68 & 0.28 & 371.2 & 26.9 & 7 \\
\hline AG-3-T & $0-15$ & 5.8 & 6.3 & 1.48 & 0.36 & 342.6 & 53.9 & 16 \\
\hline AG-4-T & $0-22$ & 6.1 & 6.5 & 1.46 & 0.41 & 408.8 & 59.8 & 15 \\
\hline AG-3\&4-SS & $15-45$ & 5.7 & 6.5 & 1.59 & 0.30 & 354.6 & 37.0 & 10 \\
\hline AG-5-T & $0-27$ & 6.3 & 6.5 & 1.68 & 0.78 & 711.5 & 99.5 & 14 \\
\hline AG-6-T & $0-25$ & 5.6 & 6.4 & 1.41 & 0.94 & 917.0 & 151.6 & 17 \\
\hline AG-5\&6-SS & $25-45$ & 6.1 & 6.5 & 1.55 & 0.29 & 411.8 & 40.8 & 10 \\
\hline AG-7-T & $0-17$ & 6.7 & 6.2 & 1.62 & 0.63 & 513.7 & 74.1 & 14 \\
\hline AG-8-T & $0-17$ & 6.2 & 6.2 & 1.49 & 0.79 & 576.7 & 77.7 & 13 \\
\hline AG-7\&8-SS & $0-33$ & 6.2 & 6.6 & 1.48 & 0.41 & 397.7 & 39.2 & 10 \\
\hline FOR $\$ \neq-10-T$ & $0-10$ & 4.5 & 5.8 & 1.22 & 2.30 & 1058.6 & 134.3 & 13 \\
\hline FOR-10-SS & $10-30$ & 4.7 & 6.4 & 1.85 & 0.47 & 316.8 & 27.8 & 9 \\
\hline FOR-9-T & $0-7$ & 5.1 & 5.8 & 1.32 & 2.24 & 1483.3 & 225.5 & 15 \\
\hline FOR-11-T & $0-12$ & 4.9 & 5.8 & 1.53 & 1.44 & 1032.0 & 142.4 & 14 \\
\hline FOR-9\&11-SS & $7-22$ & 5.1 & 6.4 & 1.66 & 0.69 & 508.6 & 56.9 & 11 \\
\hline FAL $\S-12-T$ & $0-17$ & 5.5 & 5.8 & 1.40 & 1.79 & 1287.3 & 203.9 & 16 \\
\hline FAL-12-SS & $17-33$ & 5.5 & 6.4 & 1.48 & 0.85 & 625.1 & 80.5 & 13 \\
\hline AG-13-T & $0-22$ & 5.9 & 6.5 & 1.62 & 0.93 & 963.6 & 119.7 & 12 \\
\hline AG-14-T & $0-22$ & 6.7 & 6.6 & 1.67 & 0.77 & 907.5 & 93.3 & 10 \\
\hline AG-13\&14-SS & $22-40$ & 5.9 & 6.7 & 1.56 & 0.51 & 548.4 & 55.8 & 10 \\
\hline \multirow{2}{*}{\multicolumn{9}{|c|}{ Soil $\mathrm{pH}$ before the incubation. }} \\
\hline \multicolumn{7}{|c|}{ Soil pH after 28 weeks of incubation. } & & \\
\hline \multirow{2}{*}{\multicolumn{9}{|c|}{ Organic carbon. }} \\
\hline & & & & & & & \\
\hline \multirow{2}{*}{\multicolumn{9}{|c|}{$\begin{array}{l}\| \text { Cumulative } \mathrm{N} \text { mineralized in } 28 \text { weeks. } \\
\text { \# Agricultural sites. }\end{array}$}} \\
\hline & & & & & & & & \\
\hline ** Surface so & & & & & & & & \\
\hline$\dagger$ Subsurface & & & & & & & & \\
\hline$\ddagger \quad$ Forest sites & & & & & & & & \\
\hline$\S \S \quad$ Fallow site & & & & & & & & \\
\hline
\end{tabular}

soils can be due to the rapidly mineralizable pool of organic N.

Surface soil from the fallow site (fig. 4f) had much higher cum-min $\mathrm{N}$ than the forested and agricultural areas, with the exception of site 9 . Higher cum-min $\mathrm{N}$ for this site can be attributed to the buildup of organic $\mathrm{N}$ due to grasses growing in this area for the past ten years. Before being converted to fallow in 1988, site 12 was part of the agricultural field where sites 7 and 8 are located. It is clear that taking out this site from agricultural production increased the organic $\mathrm{C}$ and $\mathrm{N}$ content of surface as well as subsurface soils by more than $200 \%$ (compared to sites 7 and 8 , table 2).

Comparison of average cum-min $\mathrm{N}$ for the agricultural, fallow, and forested soils presented in figure $4 \mathrm{~h}$ reveals that before week 13, the surface forest soils had higher cum$\min \mathrm{N}$ than the fallow site. However, after week 13, cummin $\mathrm{N}$ for fallow soil became higher than that for the forested soils. These differences in cum-min $\mathrm{N}$ trends can be due to the combination of higher mass of the slowlymineralizable $\mathrm{N}$ pool for the fallow areas and/or differences in type of microbial populations. During the 28week period, the average cum-min $\mathrm{N}$ for agricultural, forest, and fallow areas were 88,167 , and $204 \mathrm{mg} \mathrm{kg}^{-1}$, respectively (fig. $4 \mathrm{~h}$ ).

To help explain the differences in the $\mathrm{NH}_{4} / \mathrm{NO}_{3}$ trends of forested soils with all other treatments (fallow and agricultural), average ratios of $\mathrm{NH}_{4}$ to $\mathrm{NO}_{3}$ were plotted and are shown in figure 5 . The $\mathrm{NH}_{4} / \mathrm{NO}_{3}$ ratio is an index of nitrification potential occurring in the soil. Clear differences in the trends of forested versus the agricultural and fallow soils are shown. The bell shaped curve for forest soils from week 1 to 7 indicates that nitrification rates for forest soils decreased until week 3 and then increased. After a sufficiently long time (week 18 onwards) there seems to be no difference between the trends for the three

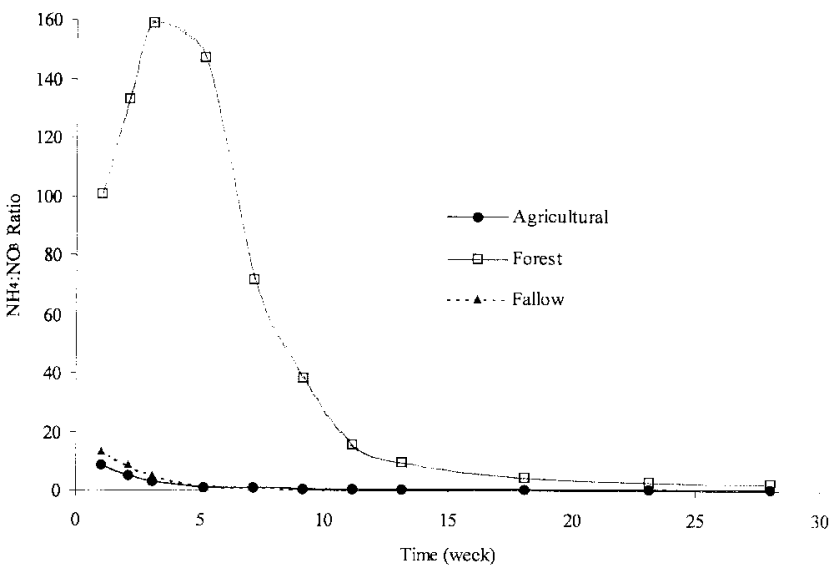

Figure 5-Average ratio of $\mathrm{NH}_{4}$ to $\mathrm{NO}_{3}$ for agricultural, forest, and fallow surface soils.

land uses. It seems that the unique pattern for forest soils is due to the different type of nitrifying organisms that may be present in the soil.

\section{DEVElopMent OF First ORDER N Mineralization Model}

Potentially Mineralizable $\mathbf{N}\left(\mathbf{N}_{0}\right)$ and Mineralization Rate Constant $(\mathbf{k})$. Potentially mineralizable $\mathrm{N}\left(\mathrm{N}_{0}\right)$ and the rate constant $(\mathrm{k})$ were estimated with the first-order model (eq. 1). Estimates of $\mathrm{N}_{0}$ and $\mathrm{k}$ for all the treatments are presented in table 3 . The $\mathrm{N}_{0}$ estimates for the surface agricultural soils

Table 3. $\mathbf{N}$ mineralization potential $\left(\mathrm{N}_{0}\right)$, first-order reaction rate constant $(\mathbf{k})$, mean squared error from the nonlinear regression, and $\mathrm{C}: \mathrm{N}$ ratio for surface and subsurface soils

\begin{tabular}{|c|c|c|c|c|c|}
\hline \multirow[b]{2}{*}{ Soil } & \multicolumn{2}{|c|}{$\begin{array}{l}\text { Mineralization } \\
\text { Potential }\left(\mathrm{N}_{0}\right)\end{array}$} & \multirow{2}{*}{$\begin{array}{c}\text { Rate } \\
\text { Constant } \\
(\mathrm{k}) \\
\left(\text { week }^{-1}\right)\end{array}$} & \multirow[b]{2}{*}{ MSE* } & \multirow[b]{2}{*}{ C:N Ratic } \\
\hline & $\left(\mathrm{mg} \mathrm{kg}^{-1}\right)$ & $\mathrm{kg} \mathrm{ha}^{-1}$ & & & \\
\hline $\mathrm{AG} \dagger-1-\mathrm{T} \ddagger$ & 78 & 262 & 0.082 & 4 & 10 \\
\hline AG-2-T & 79 & 250 & 0.099 & 9 & 11 \\
\hline AG-3-T & 55 & 163 & 0.105 & 2 & 11 \\
\hline AG-4-T & 62 & 181 & 0.094 & 2 & 10 \\
\hline AG-5-T & 107 & 360 & 0.079 & 12 & 11 \\
\hline AG-6-T & 167 & 471 & 0.080 & 12 & 10 \\
\hline AG-7-T & 73 & 237 & 0.114 & 14 & 12 \\
\hline AG-8-T & 79 & 235 & 0.112 & 13 & 14 \\
\hline FOR§-9-T & 217 & 573 & 0.155 & 73 & 15 \\
\hline FOR-10-T & 124 & 303 & 0.228 & 30 & 22 \\
\hline FOR-11-T & 134 & 410 & 0.186 & 37 & 14 \\
\hline FAL $\|-12-T$ & 228 & 638 & 0.075 & 16 & 14 \\
\hline AG-13-T & 121 & 392 & 0.100 & 18 & 10 \\
\hline AG-14-T & 110 & 367 & 0.063 & 10 & 9 \\
\hline AG-1\&2-SS\# & 27 & 91 & 0.114 & 1 & 8 \\
\hline AG-3\&4-SS & 38 & 121 & 0.093 & 1 & 8 \\
\hline AG-5\&6-SS & 48 & 149 & 0.069 & 4 & 7 \\
\hline AG-7\&8-SS & 41 & 121 & 0.096 & 2 & 10 \\
\hline FOR-10-SS & 27 & 100 & 0.203 & 1 & 15 \\
\hline FOR-9\&11-SS & 54 & 179 & 0.168 & 7 & 14 \\
\hline FAL-12-SS & 83 & 246 & 0.097 & 6 & 14 \\
\hline AG-13\&14-SS & 55 & 172 & 0.128 & 5 & 9 \\
\hline
\end{tabular}

* Mean Squared Error for the nonlinear regression fit (MSE = residual sum of squares/degrees of freedom).

+ Agricultural sites.

* Surface soil.

$\S$ Forest sites.

Fallow site.

\# Subsurface soil. 
exhibited $300 \%$ variability, which is similar to that observed for the organic $\mathrm{N}$ for these soils (tables 2 and 3). For subsurface agricultural soils, this variation was less than $50 \%$; due to the considerably lower organic $\mathrm{N}$ in the subsoil, lower frequency of drying-wetting cycles, and minimal disturbances due to tillage. Surface soils from down-gradient locations of the sites $1 \& 2,3 \& 4,5 \& 6$, and $7 \& 8$ have higher $\mathrm{N}_{0}$ than the up-gradient locations, similar to that observed for cum-min $\mathrm{N}$ trends. Estimates of rate constants for surface agricultural soils varied from 0.063 to 0.114 week $^{-1}$, exhibiting $200 \%$ variability (table 3 ). These values are within the reported range given in the literature (Schepers and Meisinger, 1994).

$\mathrm{N}_{0}$ estimates for the three forested topsoils varied from $124 \mathrm{mg} \mathrm{kg}^{-1}$ for site 10 to $217 \mathrm{mg} \mathrm{kg}^{-1}$ for site $9(175 \%$ variability). In contrast to agricultural areas, variability in $\mathrm{N}_{0}$ estimates for forest subsurface soils was higher than the surface soils (200\% variability, $27 \mathrm{mg} \mathrm{kg}^{-1}$ to $54 \mathrm{mg} \mathrm{kg}^{-1}$ ) (table 3). Higher variability in subsurface forest soils can be attributed to the greater variability in the organic matter and root density as well as diverse population of organisms in the forested subsurface soils compared with agricultural subsurface soils. The first-order reaction rate constants $(\mathrm{k})$ for surface forest soils ranged from 0.155 week $^{-1}$ for site 9 to 0.228 week $^{-1}$ for site 10 . Relating the $\mathrm{k}$ estimates for surface and subsurface forested soils to the $\mathrm{C}: \mathrm{N}$ ratios (table 3), it can be inferred that the soil with highest $\mathrm{k}$ values also has the highest $\mathrm{C}: \mathrm{N}$ ratios. This finding is similar to that reported by Bonde and Rosswall (1987) who suggested that the $\mathrm{C}: \mathrm{N}$ ratio, an index of the substrate quality, influences the mineralization rate constant.

Among all the surface soil treatments, the largest $\mathrm{N}_{0}$ was estimated for the fallow site (site 12), while the rate constant estimated for this treatment was considerably lower. This inverse relationship has also been demonstrated for some soils by Bonde and Rosswall (1987) and El-Harris et al. (1983). As mentioned before, the highest $\mathrm{N}_{0}$ for the fallow area is due to the continuous turnover of grasses, which in turn increased the organic $\mathrm{N}$ of this site. Highest subsurface $\mathrm{N}_{0}$ values were also found for the fallow soil. An examination of organic $\mathrm{C}$ and $\mathrm{N}$ for all the subsurface treatments (table 2) shows that the fallow subsurface soil also has the highest organic $\mathrm{C}$ and $\mathrm{N}$. Since this site is down-gradient to agricultural sites $7 \& 8$, it is possible that it traps fine (soluble and insoluble organic matter) as well as other organic debris carried through runoff from up-gradient areas, thereby resulting in organic matter buildup at this site.

To compare the $\mathrm{N}_{0}$ and $\mathrm{k}$ for agricultural, forested, and fallow areas, data for agricultural field (averages of upgradient and down-gradient sites; $1 \& 2,3 \& 4,5 \& 6,7 \& 8$, and $13 \& 14$ ), forested areas (averages of sites $9 \& 11$, sitespecific value for site 10), and fallow area (site specific value for site 12) are shown in figures 6 and 7 . Examination of figure 6 reveals that the average mineralizable $\mathrm{N}$ for the surface soils follows the order: fallow $>$ forested $>$ agricultural; whereas, the order for the subsurface soil is fallow $>$ agricultural $>$ forest. Soils with the low $\mathrm{N}_{0}$ seem to have the high mineralization rate constant (k) (fig. 6 and 7), indicating an inverse relationship between the $\mathrm{N}_{0}$ and $\mathrm{k}$. Moreover, the extent of differences for the $\mathrm{k}$ values due to treatments as well as depths (surface and subsurface) are much less than observed for the $\mathrm{N}_{0}$. As pointed out before, this pattern for $\mathrm{k}$ seems to be due to differences in substrate quality.

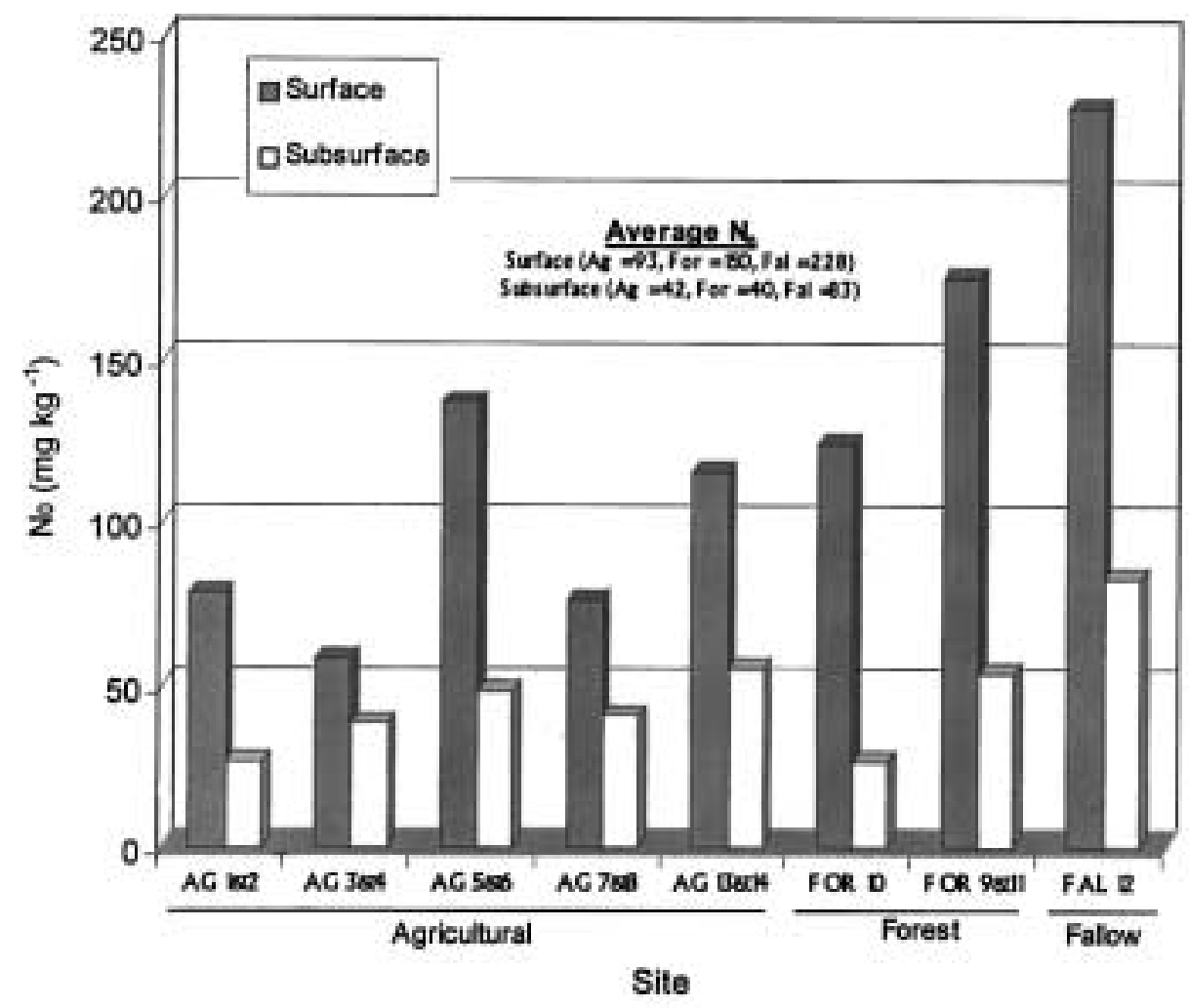

Figure 6-N Mineralization potential $\left(\mathrm{N}_{0}\right)$ of surface and subsurface soils. 


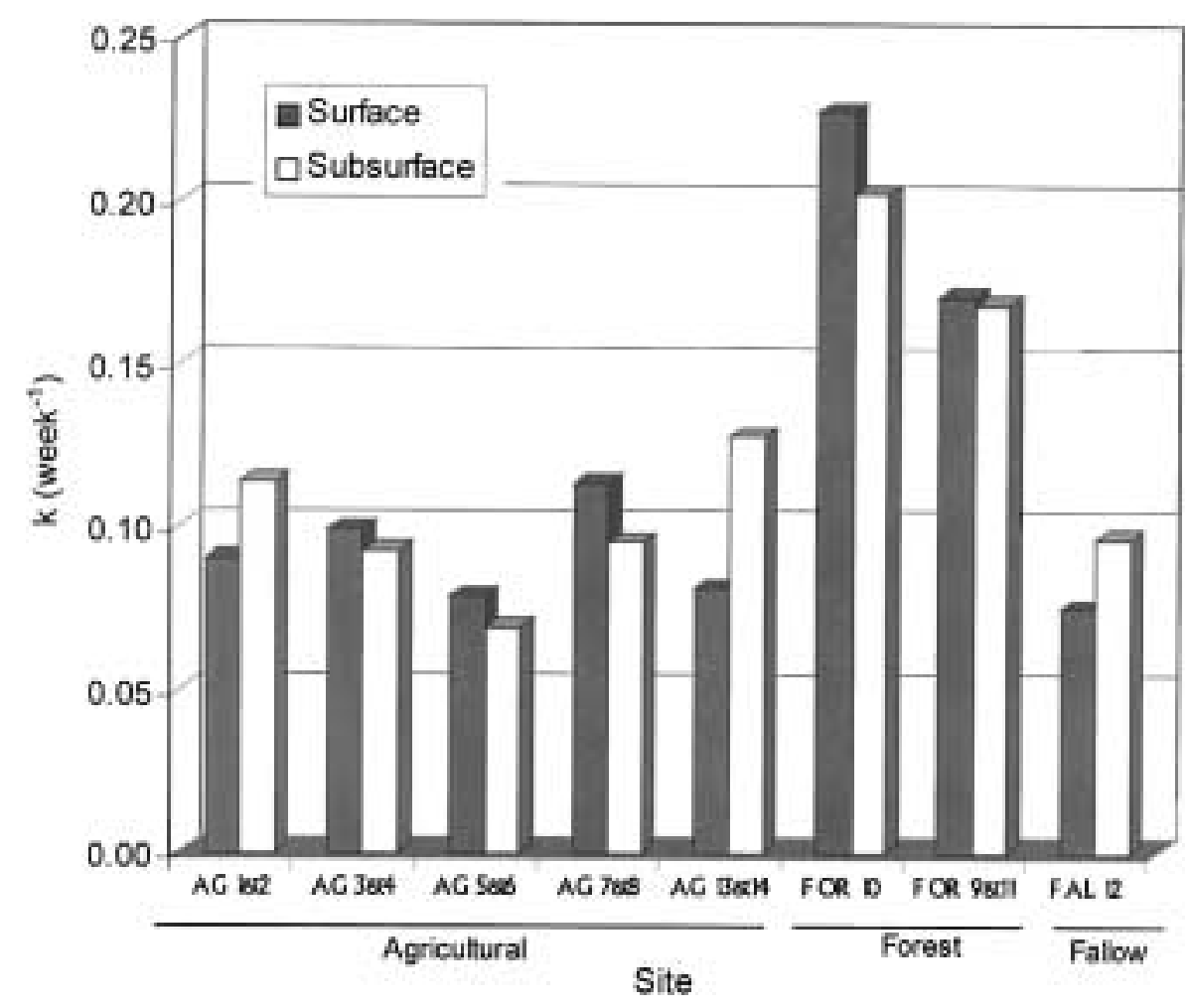

Figure 7-Mineralization rate constants (k) of surface and subsurface soils.

Table 4. Correlation between $\mathbf{N}$ mineralization potential $\left(\mathbf{N}_{0}\right)$, rate constant $(k)$, organic $N$ and $C, C: N$ ratio, and soil $\mathrm{pH}$

\begin{tabular}{lcccccccc}
\hline & \multicolumn{1}{c}{ Organic Organic } & \multicolumn{2}{c}{ C:N } & Initial & Final \\
& $\mathrm{N}_{0}$ & $\mathrm{k}$ & MSE & $\mathrm{N}$ & $\mathrm{C}$ & Ratio & $\mathrm{pH}$ & $\mathrm{pH}$ \\
\hline $\mathrm{N}_{0}$ & 1.0 & - & - & - & - & - & - & - \\
$\mathrm{k}$ & 0.0 & 1.0 & - & - & - & - & - & - \\
$\mathrm{MSE}$ & 0.7 & 0.4 & 1.0 & - & - & - & - & - \\
Organic N & 0.9 & 0.2 & 0.8 & 1.0 & - & - & - & - \\
Organic C & 0.8 & 0.4 & 0.8 & 0.9 & 1.0 & - & - & - \\
$\mathrm{C}: \mathrm{N}$ & 0.4 & 0.7 & 0.5 & 0.5 & 0.8 & 1.0 & - & - \\
Initial pH & -0.2 & -0.8 & -0.4 & -0.4 & -0.6 & -0.7 & 1.0 & - \\
Final pH & -0.7 & -0.4 & -0.7 & -0.7 & -0.8 & -0.7 & 0.6 & 1.0 \\
\hline
\end{tabular}

To examine the effects of soil properties on $\mathrm{N}_{0}$ and $\mathrm{k}$, correlation between these two and other soil properties (organic $\mathrm{C}$ and $\mathrm{N}, \mathrm{C}: \mathrm{N}$ ratio, and soil $\mathrm{pH}$ before and after the mineralization experiment), were computed and the resulting correlation matrix is shown in table 4. Organic $\mathrm{C}$ and $\mathrm{N}$ seem to be highly correlated with $\mathrm{N}_{0}$, which is to be expected. C:N ratio does not seem to be well correlated with $\mathrm{N}_{0}$. However, as noted before, $\mathrm{C}: \mathrm{N}$ ratio seems to be highly correlated with the mineralization rate constant $(\mathrm{k})$. This has been supported in other studies such as that reported by Cabrera (1986).

Potential Errors in First-order Model. To evaluate goodness of fit of the first-order model, the mean squared error $(\mathrm{MSE}=$ residual sum of squares/degrees of freedom) are presented in table 3. Values of MSE for all the surface soils show that, the three highest MSE values correspond to the forested soils (table 3). The best fit was obtained for agricultural soils at sites $3 \& 4$ followed by sites $1 \& 2$. The best and worst fit obtained for agricultural and forest soils are shown in figure 8. Examination of the fit (fig. 8) reveals that the shape of the cumulative $\mathrm{N}$ mineralization curve (fitted) for forested soils is different from those obtained for the agricultural sites. Data from forested soils do not fit well to the first-order model after week 7 (fig. 8). This is probably due to the fact that organic matter in forest soils is more ligniferous and aromatic in nature than the agricultural soils, and therefore, is more resistant to decomposition than the residues of crop or grass origin. It seems that the double exponential model may provide a better fit to all the forested soils since it attempts to model the slow and fast organic $\mathrm{N}$ pool separately. The case for double exponential model for forested surface soils is also evident from the fact that the first order model fits the subsurface forest soils well. Fitting the double exponential model to forest and agricultural soils is discussed in a later section. The better fit for the subsurface forest soils is due to the fact that the slow organic $\mathrm{N}$ pool decreases considerably with depth. The degree of fit seems to relate well with $\mathrm{N}_{0}$, organic $\mathrm{C}$ and $\mathrm{N}, \mathrm{C}: \mathrm{N}$ ratio, and final soil $\mathrm{pH}$ (table 4). Examination of the correlation between the initial and final $\mathrm{pH}$ with other variables reveals some interesting points. While there is a high negative correlation between the $\mathrm{N}_{0}$ and final $\mathrm{pH}$, correlation with initial $\mathrm{pH}$ is small. The high negative correlation between $\mathrm{k}$ and the initial $\mathrm{pH}$ indicates that for more acidic soil, the $\mathrm{k}$ will be higher.

Temperature Effects on $\mathbf{N}$ Mineralization. Mineralization of organic $\mathrm{N}$ is attained through biological processes and therefore, the mineralization rate is affected by temperature. Temperature dependence of $\mathrm{N}$ mineralization is well established (Stanford et al., 1973; Campbell et al., 1981). Several equations have been proposed for incorporating effects of temperature on the $\mathrm{N}$ mineralization rate. One of the most often-used method is based on the change in the reaction rate for every $10^{\circ} \mathrm{C}$ increase in temperature range from 0 to $35^{\circ} \mathrm{C}$. Stanford et al. (1973) reported a temperature coefficient $\left(Q_{10}\right)$ of 2 for 


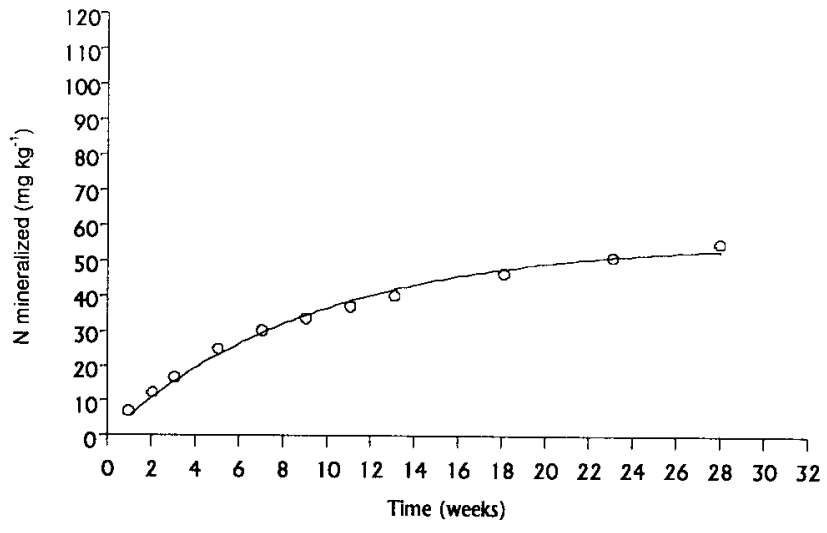

(a) Agricultural Site 3

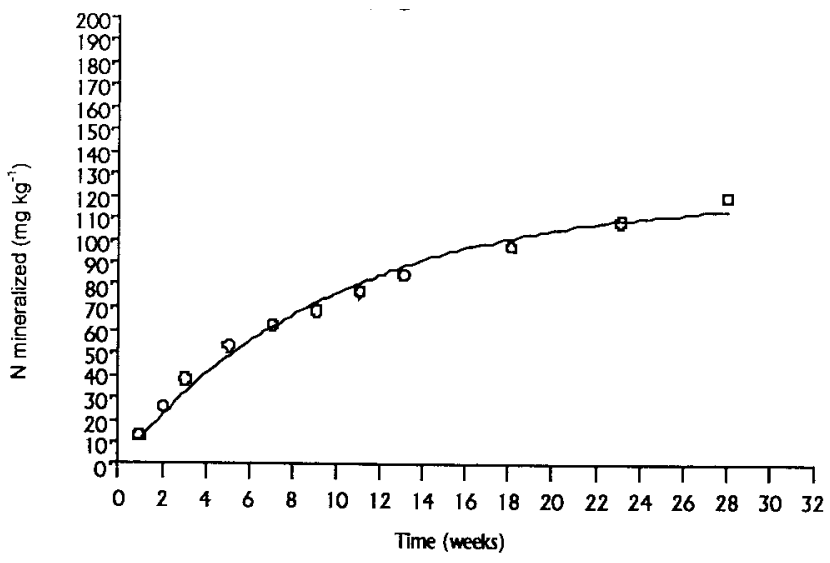

(b) Agricultural Site 13

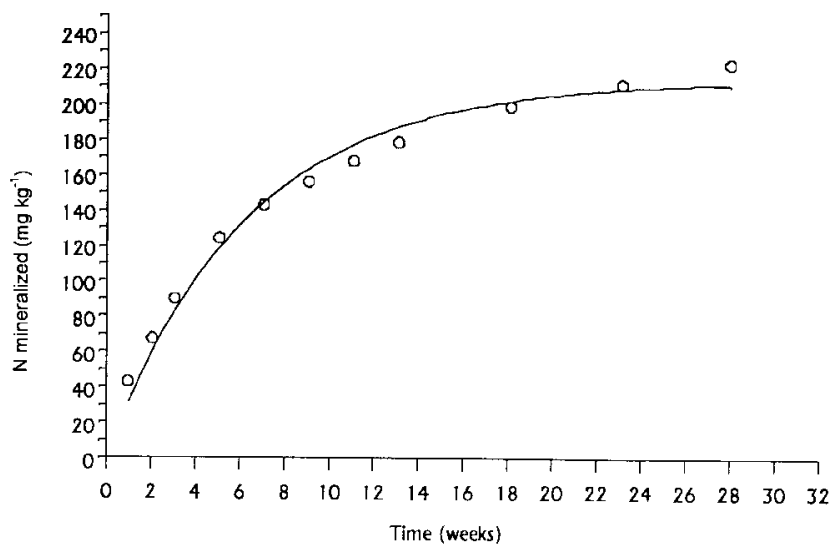

(c) Forest Site 9

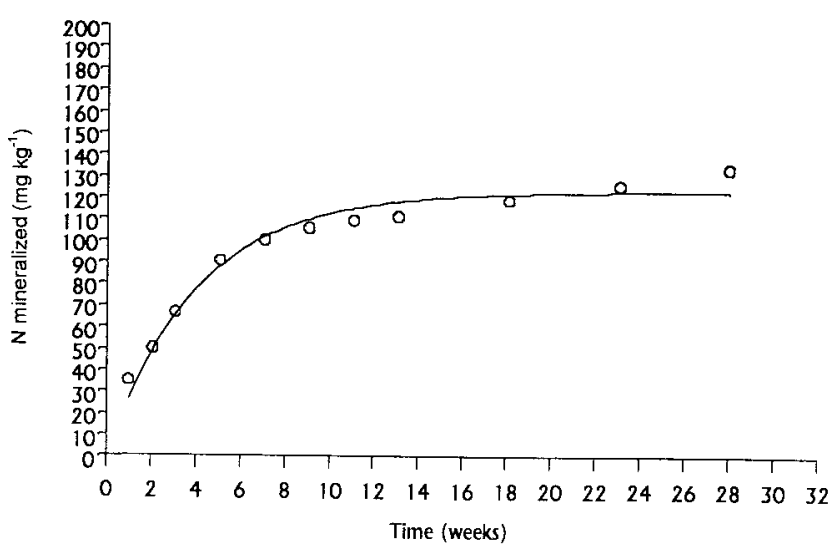

(d) Forest Site 10

Figure 8-Good and poor first-order model fit for agricultural and forest surface soils.

most soils, indicating that for each $10^{\circ} \mathrm{C}$ increase (within 0 to $35^{\circ} \mathrm{C}$ ) the mineralization rate constant doubles.

Using a $\mathrm{Q}_{10}$ of 2 (Stanford et al., 1973), average values of mineralization rate constant $(\mathrm{k})$ for surface soils of agricultural, forest, and fallow areas for $5,10,15$, and $35^{\circ} \mathrm{C}$ were estimated and are presented in table 5 . To evaluate the temperature effects on prediction of $\mathrm{N}$ mineralization in the field, mass of $\mathrm{N}$ mineralized per unit area $\left(\mathrm{kg} \mathrm{ha}^{-1}\right)$ after four weeks is also presented. A large variation in $\mathrm{N}$ mineralization is shown for the four temperatures. This large variation in $\mathrm{N}$ mineralization warrants adjustments in mineralized $\mathrm{N}$ based on the daily temperature for $\mathrm{N}$ mass balance studies.

Soil Moisture Effects on N Mineralization. In addition to temperature, soil moisture content also modifies the $\mathrm{N}$ mineralization process (Stanford and Epstein, 1974;

Table 5. Effects of temperature on field $\mathbf{N}$ mineralization predictions for four temperature ranges for surface soils from agricultural, forest and fallow areas

\begin{tabular}{|c|c|c|c|c|c|c|c|c|c|c|}
\hline \multirow[b]{2}{*}{ Soil } & \multirow[b]{2}{*}{ Site } & \multirow{2}{*}{$\begin{array}{c}\mathrm{N}_{0} \\
\left(\mathrm{mg} \mathrm{kg}^{-1}\right)\end{array}$} & \multicolumn{4}{|c|}{ Rate constant $(\mathrm{k})\left(\right.$ week $\left.^{-1}\right)$} & \multicolumn{4}{|c|}{$\begin{array}{l}\text { Predicted N Mineralization } \\
\left(\mathrm{kg} \mathrm{ha}^{-1}\right) \text { for } 4 \text { weeks }\end{array}$} \\
\hline & & & $5^{\circ} \mathrm{C}$ & $15^{\circ} \mathrm{C}$ & $25^{\circ} \mathrm{C}$ & $35^{\circ} \mathrm{C}$ & $5^{\circ} \mathrm{C}$ & $15^{\circ} \mathrm{C}$ & $25^{\circ} \mathrm{C}$ & $35^{\circ} \mathrm{C}$ \\
\hline \multirow[t]{3}{*}{ Irface } & & 93 & & & & & 14 & & 50 & 01 \\
\hline & & 1 & & & & & & & 135 & \\
\hline & Fallow & 228 & 0.009 & 0.019 & 0.038 & 0.075 & 23 & 47 & 90 & 165 \\
\hline
\end{tabular}

Cassman and Munns, 1980; Myers et al., 1982; Rice and Havlin, 1994). The first significant work of modeling moisture effects on mineralization, undertaken by Stanford and Epstein (1974), found a linear relationship between the $\mathrm{N}$ mineralization and soil moisture within the range of field capacity $(-0.03 \mathrm{MPa})$ to wilting point $(-1.5 \mathrm{MPa})$. The linear relationship was later studied by Myers et al. (1982) on five Australian and 32 Canadian soils. They confirmed the linear relationship between $-0.03 \mathrm{MPa}$ and $-4.0 \mathrm{MPa}$ for 22 soils, however, for 10 soils a curvilinear response was observed. Myers et al. (1982) proposed a general model:

$$
y=b x+(1-b) x^{2}
$$

where $\mathrm{y}$ is the net $\mathrm{N}$ mineralized expressed as the proportion of the maximum rate determined from an incubation study, $x$ is normalized moisture content, and $b$ is a measure of the degree of curvature. Normalized moisture content was defined as $\left(\mathrm{W}-\mathrm{W}_{0}\right) /\left(\mathrm{W}_{\max }-\mathrm{W}_{0}\right)$, where $\mathrm{W}$ is the gravimetric moisture content and $\mathrm{W}_{0}$, and $\mathrm{W}_{\max }$ are moisture contents at $-4 \mathrm{MPa}$ and $-0.03 \mathrm{MPa}$ (moisture content at which maximum $\mathrm{N}$ mineralization occurs). The challenge with using equation 2 is the selection of a value 
for $\mathrm{b}$. For most soils, $\mathrm{b}$ can be taken to be 1 and we get the linear form $\mathrm{y}=\mathrm{x}$ which is similar to that reported by Stanford and Epstein (1974). Myers et al. (1982) reported curvilinear behavior was observed for soils with heavy grass stands and higher humic colloids. Therefore, it is possible that our fallow site (site 12) in the watershed that is under a grass stand for the past several years may exhibit the curvilinear relationship.

For this study, the effect of soil moisture was modeled with both the Stanford and Epstein (1974) as well as Myers et al. (1982) models. Measured values of $\mathrm{W}_{\max }$ and $\mathrm{W}_{0}$ were used for demonstrating the extent of $\mathrm{N}$ mineralization variability that can be expected due to observed moisture variations in the watershed. Mean moisture levels of 9,7 , and $13 \%$ observed in the watershed by Menelik et al. (1990) in July, August, and November were used to examine the variation in $\mathrm{N}$ mineralization. Results for the agricultural, forest, and fallow soils are presented in table 6 . Variations in the $\mathrm{N}$ mineralization between July and November are more than two fold. These values are presented for providing an example of the influence of moisture content. Prediction of mineralization of $\mathrm{N}$ in the field from the laboratory-derived results will require simultaneous consideration of temperature as well as moisture. Considerably large variation in $\mathrm{N}$ mineralization shows that field application of $\mathrm{N}$ mineralization models warrants consideration of soil moisture effects. It should be noted that assuming $b$ to be 1 for fallow and forested soils in the watershed may introduce uncertainties in quantifying moisture effects on mineralization. However, for most soils, the value of $b$ is not statistically different from 1 (Myers et al., 1982), and the fact that soil factors governing the degree of curvature (b) are not yet defined, assumption of a linear relationship $(b=1)$ is reasonable for quantifying moisture effects for most soils.

It should be noted that in addition to soil moisture and temperature, changes in the soil structure may also affect $\mathrm{N}$ mineralization. Since the structure of soil material used for aerobic leaching procedure was somewhat altered, it may have introduced a certain level of uncertainty in predicting $\mathrm{N}$ mineralization under field conditions. Efforts are in progress to verify the first-order model derived in this study in predicting the field $\mathrm{N}$ mineralization (Shukla, 2000). Preliminary results (data not shown) indicate that predicted values of $\mathrm{N}$ mineralization using daily soil temperature and moisture are close (within 10\%) to the field measured values.

Table 6. Effects of soil moisture on field $\mathbf{N}$ mineralization predictions for three gravimetric moisture levels (mean moisture in July, August, and November) for surface soils from agricultural, forest, and fallow areas

\begin{tabular}{|c|c|c|c|c|c|}
\hline \multirow[b]{2}{*}{ Soil } & \multirow[b]{2}{*}{ Site } & \multirow[b]{2}{*}{$\begin{array}{c}\mathrm{N}_{0} \\
\left(\mathrm{mg} \mathrm{kg}^{-1}\right)\end{array}$} & \multicolumn{3}{|c|}{$\begin{array}{l}\text { Predicted N Mineralization } \\
\left(\mathrm{kg} \mathrm{ha}^{-1}\right) \text { for } 4 \text { Weeks for } \\
\text { Three Moisture Levels* }\end{array}$} \\
\hline & & & $\begin{array}{c}9 \% \\
\text { (Jul) }\end{array}$ & $\begin{array}{c}7 \% \\
\text { (Aug) }\end{array}$ & $\begin{array}{c}13 \% \\
\text { (Nov) }\end{array}$ \\
\hline \multirow[t]{3}{*}{ Surface } & Agricultural & 93 & 17 & 6 & 40 \\
\hline & Forest & 150 & 42 & 14 & 98 \\
\hline & Fallow & 228 & 31 & 10 & 72 \\
\hline
\end{tabular}

* Field capacity of $22 \%$ measured for surface soil $(0$ to $15 \mathrm{~cm})$ was used in the computations. Three moisture levels represent the mean moisture levels observed in July, August, and November in the watershed. Moisture data (by weight) from Menelik et al. (1990).

\section{Evaluation of Two Pool Approach for Modeling N Mineralization}

It has been argued that a two-pool model (also known as double exponential or two simultaneous reaction model) fits the lab $\mathrm{N}$ mineralization better than the single exponential model (Molina et al., 1980). Deans et al. (1986) used N mineralization data of Stanford and Smith (1972) to show that the single exponential model does not apply to the first 12 weeks of incubation and proposed the double exponential model:

$$
\mathrm{N}_{\min }=\mathrm{N}_{0} \mathrm{~S}\left(1-\mathrm{e}^{-\mathrm{ht}}\right)+\mathrm{N}_{0}(1-\mathrm{S})\left(1-\mathrm{e}^{-\mathrm{kt}}\right)
$$

where $S$ and $(1-S)$ represent the labile and recalcitrant organic $\mathrm{N}$ fractions decomposing at specific rates $\mathrm{h}$ and $\mathrm{k}$, respectively. Together, single and double exponential models are the most widely used models (Cabrera et al., 1994). The double exponential model considers substrate quality which is more important while modeling the $\mathrm{N}$ mineralization of fallow or forest soils.

The data from this study were fitted to the double exponential model in equation 3 using SAS (SAS Institute, 1997) to test whether a better fit may be obtained. However, results for the soils in the Nomini Creek watershed indicated that the single exponential model was better than the double exponential model. Factors causing the uncertainty in fitting the double exponential model included: (a) in most cases the approximate Hessian matrix was singular, signifying the determinant (differential matrix) to be near zero to result in questionable results; (b) in some cases the solution failed to converge; and (c) for almost all the soils the values for $\mathrm{k}$ were extremely high (to the order of $10^{3}$ to $10^{11}$ ) compared to literature reported values (ranging from 0.2 to 7 ) (Deans et al., 1986). Exceptionally high values of $h$ combined with smaller values of $\mathrm{S}$ made the contribution of the labile organic $\mathrm{N}$ fraction towards $\mathrm{N}$ mineralization almost zero, thereby reducing the double exponential model (eq. 3) to a single first-order model (eq. 1). Overall, it seems that for soils in the watershed, the double exponential model did not offer any improvement over the single exponential model.

\section{CONCLUSIONS}

A long-term aerobic incubation and leaching technique was used to measure $\mathrm{N}$ mineralization of surface and subsurface soils from agricultural, forest, and fallow sites in a Coastal Plain watershed. Potentially mineralizable N $\left(\mathrm{N}_{0}\right)$ and reaction rate constant $(\mathrm{k})$ were estimated by using the first-order model of Stanford and Smith (1972) and nonlinear regression. Effects of land use, location, and slope on the $\mathrm{N}$ mineralization potential of soils were determined. The following conclusions were drawn from this study:

- A considerably large variability in cumulative $\mathrm{N}$ mineralized, $\mathrm{N}$ mineralization potential, and firstorder reaction rates was found for the surface soils from agricultural areas. These differences signify that a considerable uncertainty will be introduced in the field predictions of $\mathrm{N}$ mineralization, if a single $\mathrm{N}$ mineralization rate $(\mathrm{k})$ and $\mathrm{N}_{0}$ value is used for similar soil type within the watershed. 
- Land use had a profound effect on the $\mathrm{N}$ mineralization potential of the surface soils. Forested soils exhibited much higher $\mathrm{N}$ mineralization potential than agricultural soils. Therefore, it is important to measure $\mathrm{N}_{0}$ separately for modeling $\mathrm{N}$ mineralization in the forest soils.

- For subsurface soils, the differences among the land uses were much less than those found for the surface soils. Within the same land use, variability in $\mathrm{N}_{0}$ for the subsurface soils was also much less than that for the surface soils. Less variability in the subsurface soils indicates that measured values of $\mathrm{N}_{0}$ at few sites may be sufficient for extrapolation to similar soils under different land uses.

- The first-order (single exponential) model was found to be adequate for surface soils from agricultural and fallow areas, however it was less suitable for forested surface soils. Lack of good fit for the forested areas may be due to different substrate quality ( $\mathrm{C}: \mathrm{N}$ ratio) of the forested surface soils. The results thus indicate the potential for greater uncertainty in $\mathrm{N}$ mineralization predictions for forest soils compared to those for agricultural soils.

- Consideration of a two-pool (labile and recalcitrant) approach in the double exponential model for the forested as well other soils did not offer significant improvements over the first-order model.

- For subsurface soils, the first-order model proved to be adequate for all the three land uses. This was attributed to the considerably lower amount of the slow mineralizable pool in this layer compared to that for the surface layer.

- Field soil temperature and moisture are expected to have a considerable effect on mineralized $\mathrm{N}$. Therefore, soil moisture and temperature effects should be incorporated into $\mathrm{N}$ dynamics models.

Given the differences in $\mathrm{N}$ mineralization within agricultural and forest areas, $\mathrm{N}$ mineralization component should be included in the $\mathrm{N}$ mass balance studies Variability in the $\mathrm{N}$ mineralization potential for the surface agricultural soils in this study warrants that these differences be considered in the nutrient management plans to minimize the leaching of excess $\mathrm{N}$ to the groundwater.

ACKNOWLEDGMENT. Funds for this study were provided by the United States Geological Survey (USGS), and Virginia Department of Conservation and Recreation, Division of Soil and Water Conservation. Authors wish to acknowledge assistance of Dexter Davis and A. M. Payne in soil sampling. Assistance of David Mitchem in the soil chemical analysis is greatly appreciated.

\section{REFERENCES}

Bonde, T. A., and T. Rosswall. 1987. Seasonal variation of potentially mineralizable nitrogen in four cropping systems. $J$. Soil Sci. Soc. America 51(6): 1508-1514.

Burger, J. A. 1995. Forest Soils Lab Manual. Blacksburg, Va.: Dept. of Forestry, Virginia Tech.

Burger, J. A., and R. Pritchett. 1984. Effects of clearfelling and site preparation on nitrogen mineralization in a southern pine stand. J. Soil Sci. Soc. Am. 48(6): 1432-1437.

Cabrera, M. L. 1986. Studies on the prediction of nitrogen mineralized soil organic matter under field conditions. Ph.D. diss. Manhattan, Kans.: Kansas State University (Diss. Abstr. DA8705829).

Cabrera, M. L., D. E. Kissel, and M. F. Vigil. 1994. Potential nitrogen mineralization: Laboratory and field evaluation. In Soil Testing: Prospects for Improving Nutrient

Recommendations. SSSA Special Pub. 40. Madison, Wis.: Soil Science Society of America.

Campbell, C. A., R. J. K. Myers, and K. L. Weier. 1981. Potentially mineralizable nitrogen, decomposition rates and their relationship to temperature for five Queensland soils. Australian J. Res. 19(4): 323-332.

Cassman, K. G., and D. N. Munns. 1980. Nitrogen mineralization as affected by soil moisture, temperature and depth. J. Soil Sci. Soc. America 44: 1233-1237.

Deans, J. R., J. A. E. Molina, and C. E. Clapp. 1986. Models for predicting potentially mineralizable nitrogen and decomposition rate constants. J. Soil Sci. Soc. Am. 50(2): 323-326.

El-Harris, M. K., V. L. Cochran, L. F. Elliot, and D. F. Bezdicek. 1983. Effect of tillage, cropping and fertilizer management on soil nitrogen mineralization potential. J. Soil Sci. Soc. Am. 47(6): 1157-1161.

Menelik, G., R. B. Reneau, and D. C. Martens. 1990. Effects of tillage and nitrogen fertilization on nitrogen losses from soils used for corn production. Blacksburg, Va.: Virginia Water Resources Research Center.

Molina, A. E., C. E. Clapp, and W. E. Larson. 1980. Potentially mineralizable nitrogen in soil: The simple exponential model does not apply for the first 12 weeks of incubation. J. Soil Sci. Soc. America 44(2): 442-443.

Mostaghimi, S., U. S. Tim, P. W. McClellan, J. C. Carr, R. K. Byler, T. A. Dillaha, and V. O. Shanholtz. 1989. Watershed/water quality monitoring for evaluating BMP effectiveness-Nomini Creek watershed. Pre-BMP Evaluation Report No. N-P1-8811. Blacksburg, Va.: Dept. of Conservation and Historic Resources, Div. of Soil and Water Conservation, Dept. of Agricultural Engineering, Virginia Polytechnic Institute and State University.

Myers, R. J. K., C. A. Campbell, and K. L. Weier. 1982. Quantitative relationship between net nitrogen mineralization and moisture content of soils. Canadian J. Soil Sci. 62(1): 111-124.

Rice, C. W., and J. L. Havlin. 1994. Integrating mineralizable nitrogen indices into fertilizer nitrogen recommendations. In Soil Testing: Prospects for Improving Nutrient Recommendations. SSSA Special Pub. 40. Madison, Wis.: Soil Science Society of America.

SAS Institute. 1997. Statistical Analyses Software. Cary, N.C.: SAS Institute Inc.

Schepers, J. S., and J. J. Meisinger. 1994. Field indicators of nitrogen mineralization. In Soil Testing: Prospects for Improving Nutrient Recommendations. SSSA Special Pub. 40. Madison, Wis.: Soil Science Society of America.

Shukla, S. 2000. A framework for evaluating BMP effects on N discharges from watersheds. Ph.D. diss. Blacksburg, Va.: Dept. of Biological Systems Engineering, Virginia Polytechnic Institute and State University.

Shukla, S., and S. Mostaghimi. 1998. A framework for evaluating BMP effects on $\mathrm{N}$ discharges from watersheds. ASAE Paper No. 98-2008. St. Joseph Mich.: ASAE.

Soil Science Society of America. 1987. Glossary of Soil Science Terms. Madison, Wis.: SSSA.

Stanford, G., and S. J. Smith. 1972. Nitrogen mineralization of soils. In Proc. Soil Sci. Soc. America 36(3): 465-472.

Stanford, G., M. H. Frere, and D. H. Schwaninger. 1973. Temperature coefficient of soil nitrogen mineralization. Soil Science 115(4): 321-323.

Stanford, G., and E. Epstein. 1974. Nitrogen mineralization-water relation in soils. J. Soil Sci. Soc. Am. 38(1): 103-107. 